\title{
Comunicação suplementar e/ou alternativa: abrangência e peculiaridades dos termos e conceitos em uso no Brasil**
}

\author{
Augmentative and alternative communication: scope and peculiarities \\ of terms and concepts in Brazil
}

\section{Regina Yu Shon Chun*}

*Fonoaudióloga. Pós-Doutorado em Linguística pela Universidade Estadual de Campinas (Unicamp). Docente do Curso de Fonoaudiologia da Unicamp e do Programa de Mestrado Profissional Saúde,

Interdisciplinaridade e Reabilitação da FCM/Unicamp. Endereço para correspondência: R. Tessália Vieira de Camargo, 126 - Cidade Universitária Zeferino Vaz - Campinas - São Paulo CEP 13084-971

(reginayu@fcm.unicamp.br).

**Trabalho Realizado na Unicamp.

Artigo de Revisão de Literatura e Revisão Sistemática

Artigo Submetido a Avaliação por Pares

Conflito de Interesse: não

Recebido em 13.06.2008.

Revisado em 13.07.2008; 28.10.2008.

Aceito para Publicação em 03.02.2009.

\begin{abstract}
Background: Augmentative and Alternative Communication (AAC) is expanding in our country, however it is still not a widely recognized practice. Although the term "Augmentative and Alternative Communication" is well defined in the international literature, in our country there is no official and/or accepted version. Aim: to review the terms used in Brazil and to discuss their implications, taking as a reference the policies and recommendations of Isaac - International Society for Augmentative and Alternative Communication. Method: a review of national Journals was made, consulting Lilacs and SciELO database, until the year of 2007. Results: the following versions were found: Comunicação Alternativa e Suplementar, Comunicação Alternativa, Comunicação Suplementar e/ou Alternativa, Sistemas Alternativos e Facilitadores de Comunicação, Comunicação Suplementar, Comunicação Alternativa e Ampliada. Conclusion: it is important for a given version/term, besides being adopted by its own use, to maintain the original intended sense and to be in consonance with recommendations/policies of the field it belongs, such as those proposed by Isaac. This is a relevant discussion for the consolidation and strengthening of AAC in Brazil and also for the establishment of descriptors in the field of Health Sciences.
\end{abstract}

Key Words: Speech-Language Pathology; Terminology; Nonverbal Communication.

\section{Resumo}

Tema: a Comunicação Suplementar e/ou Alternativa (CSA) vem se expandindo em nosso país, porém, ainda não se constitui em prática de amplo conhecimento. Na literatura internacional situa-se como "Augmentative and Alternative Communication" (AAC), contudo, não existe uma versão oficial e/ou consagrada em nosso meio. Objetivo: fazer uma revisão das versões brasileiras em uso e discutir suas implicações, tomando como referência as publicações da International Society for Augmentative and Alternative Communication (Isaac). Método: foi feito um levantamento dos periódicos nacionais nas bases Lilacs e SciELO até 2007. Resultados: foram encontradas várias versões: Comunicação Alternativa e Suplementar, Comunicação Alternativa, Comunicação Suplementar e/ou Alternativa, Sistemas Alternativos e Facilitadores de Comunicação, Comunicação Suplementar, Comunicação Alternativa e Ampliada. Conclusão: é importante que uma versão, além da consagração pelo próprio uso, carregue os sentidos originais a que se propõe bem como esteja em consonância com recomendações/políticas da área, como as propostas pela Isaac. Trata-se de discussão relevante para consolidação e fortalecimento da CSA no Brasil bem como para a definição dos descritores em Saúde.

Palavras-Chave: Patologia da Fala e da Linguagem; Terminologia; Comunicação Não Verbal. 


\section{Introduction}

The Augmentative and Alternative Communication (AAC) has been expanding in our country, but it is not yet a widely recognized practice. In Brazil, there is no official or established version of ACC. Thus, this article aims to discuss the terms and concepts used in the ACC in our country and its implications, using as a subsidy, policies and recommendations concerning the terminology of the International Society for Augmentative and Alternative Communication ISAAC.

It is observed that AAC has extended beyond the scope of clinical practices and specialized institutions. It covers several City Halls through their Education and Health Secretaries, in addition to the significant development of research in the academic field1.

As a result of this growth, the First International Conference of Language and Communication of People with Disabilities and I Brazilian Conference on Augmentative and Alternative Communication - ISAAC Brazil (Rio de Janeiro, 2005); and II Brazilian Conference on Alternative Communication (Campinas, Sao Paulo, 2007) were carried thorough. The differentiation of these meetings, similarly to what occurs in ISAAC's international events, was the involvement of AAC users and their families. It is also highlighted the creation of the AAC Committee on the Department of Language of the Brazilian Society of Speech-Language Pathology and Audiology in its 14th Brazilian Conference (2006, Salvador/Bahia, Brazil).

As Reily1 states, specialized institutions had a significant role in the production of knowledge about methods of working with people with special needs and contributed to further training of professionals. The author also adds that, given the current school inclusion policies (mainstream), such institutions are faced with serious challenge to in order to revise and meet their goals.

Considering that the pioneer studies in AAC in our country dates from the late 1970s1-3, a significant experience in this field has been accumulated. However, the first national forum on terminology was only conducted at the II Brazilian Conference on Alternative Communication - ISAAC Brazil in 2007.

In this context, the revision and circulation of terms and concepts - its scope, characteristics and uses - is fundamental among professionals in the ACC practice in our country, beginning by the expression augmentative and alternative communication as well as non-speech, nonverbal and nonspeaking communication.

This is a reflection required by the multidisciplinary, interdisciplinary and transdisciplinary nature of this area, which leads to use and interpretation of various terms, often to describe the same phenomenon and actions. This aspect was pointed at one of the first ISAAC publications 4 with the aim of searching for a logical and consistent terminology and of guiding its use.

Besides the issues of the translation from English to Portuguese, such words carry different meanings and connotations depending on the area of knowledge and theoretical framework adopted. Lloyd5 pointed in 1985 that there is not a consensus in the terminology, a situation that persists today and also occurs in Brazil. Still, according to the author, in great part of the international literature, none of the most used terms are considered ideal descriptors. Thus, an ISAAC Committee was created in 1985 to discuss the terminology. Several forums, which resulted in several publications4-8, letters to editors, etc, were created. A glossary of terms can be found at the ISAAC website (In: http:/ /www.isaac-online.org/em/aac/what_is.html. Accessed on:15/01/2008).

Considering the aim of investigating the terms used in national publications referring to AAC, a survey of national periodicals was carried out using LILACS and SCIELO databases up to 2007. The key words comunicação alternativa, comunicação suplementar e alternativa, comunicação alternativa e ampliada, comunicação alternativa e facilitadora, were used on the search considering their occurrence in titles and abstracts available online. A bibliographic search was also conducted with the only one brazilian descriptor: sistemas de comunicação alternativos e aumentativos, corresponding to the AAC set of descriptors Health Sciences - DeCS (In: www.bireme.br. Accessed on 11/07/08).

AAC Terms and Concepts in circulation among professionals in Brazil: its scope, characteristics and uses

In the Lilacs database, 11 references published on 2007 were found - nine for the keywords comunicação alternativa e suplementar, and 2 for comunicação alternativa e facilitadora. In the SCIELO database, three results were found - one reference to each of the following keywords: 
comunicação alternativa e suplementar, comunicação alternativa e comunicação alternativa e ampliada. By way of illustration, it is important to mention that no matching references were found in MEDLINE .for those brazilian key words (access on 11/07/08). The results are indicated in Table 1.

It is verified from the analysis of titles and abstracts available online, the occurrence of the following versions for Brazilian AAC: Comunicação Alternativa e Suplementar9-15, Comunicação Alternativa16-18, Comunicação Suplementar e/ou Alternativa19-20, Sistemas Alternativos e Facilitadores de Comunicação 21-22, Comunicação Suplementar 23 and Comunicação Alternativa e Ampliada24 (see Table 2).

It is important to emphasize that in two pioneer references 1-25, published in national journals but not found in these databases, the use of the terms Comunicação Suplementar e/ou Alternativa and Comunicação Alternativa, can be observed respectively.

The search with the descriptor sistemas de comunicação alternativos e aumentativos resulted in nine references. From these, five were found through the mentioned keywords13,14,18,20-23. Only one reference6 that does not appear in previous results was included in Table 2. Three articles were excluded for being publications from other countries.

The following Table shows the references by occurrence and year of publication.

It was verified that Pires e Limongi23 employed Comunicação Suplementar on the title and used sistema de comunicação suplementar e/ou alternativa in the abstract (result not computed in Table 2).

It is observed that some authors21-22 employed different versions in more recent studies17. In a latter one, Capovilla et al17 presented a retrospective of the studies of a AAC group which presents extensive scientific production. However, such references were not found on the searched databases.

Similarly, the denomination Comunicação Alternativa e Ampliada is used by a group of researchers and professionals, mostly from Rio de Janeiro, with significant production in the area as Nunes 3 describes. However, their publications are not included in the investigated databases.

The versions Comunicação Alternativa e Suplementar and Comunicação Suplementar e /ou Alternativa were the most prevalent ones found in publications from Sao Paulo. The original reference date of this designation is from 19912. As explained in previous studies2-20, some authors consider Augmentative as Supplemental and, in this context, supplemental to speech. Alternative, used in conjunction with Augmentative, applies to individuals with impaired speech. These individuals necessitate a way, not to extend ("augment") speech, but that is alternative to it. These authors prefer the term Augmentative (used alone) to the Alternative, stressing that even the more severely impaired individuals produce some vocalization. Thus, it is not the case of providing an alternative to speech, but of supplementing it.

The isolated use of the terms in a reference to AAC - Alternative Communication or Augmentative Communication - is constituted based on one of the consensus points regarding the terminology in the Isaac publications. It is recommended that the single use occurs only in special situations, given the restrictive nature of these options. Lloyd e Kangas4 clarify that the term Alternative Communication should only be used in the approaches that clearly are characterized as an alternative to natural speech and / or writing.

According to these authors, the words Augmentative Communication should be used when it clearly adds an environment that is natural to speech and / or writing. They also clarify that this designation should not be used if there is no involvement of natural speech and / or writing. The authors recommended the use of both terms: Augmentative and Alternative Communication, or the AAC abbreviation after its first use.

Lloyd e Kangas4 highlight that non-English speaking countries have no difficulty in the translation of "Alternative Communication", because it is an expression which has similar meanings in different languages. However, they stress that this is not the case with "Augmentative Communication". There are difficulties in terms of translation to maintain the meaning desired in the original language. The authors indicate a problem of definition and logic in the translation of "augmentative communication". In fact, with regards to this term, there is no consensus among the Brazilian versions, as shown in Table 2.

According Reily1, the term augmentative is not in the Portuguese dictionary, and if it was appropriate to create a neologism, this term would not be the most appropriate one. "In our view, why not account the sense of augmentative, which brings the connotation of help, of serving as support, complementing, as an addition to other means of communication already employed, such as gestures, gaze, facial expressions, smile, and 
even changes in muscle tonicity, beyond the speech or vocalization, which may be present. "(Op.cit., P.28).

Another term mentioned by Lloyd5 is nonspeech communication. This has been used to refer to individuals who "do not speak." This term, from a literal point of view, could be translated as "communication without speaking". The term nonspeech is shortly referenced with this intention in Brazil. There are usually references to "nonspeakers" or "individuals without functional speech." However, it is known that there is no absolute absence of speech neither as referring to "a speechless communication".

In this direction, some studies11,19-20 intend to show that language is present when orality/ speech is compromised. Vasconcelos 11 clarifies that the non-oralization (not to speak), does not exclude the subjects from a relationship speech / language. They are "speakers of the language" although they do not present conditions to develop "articulated speech". This position is shared by Chun19. Chun cautions that lack of speech should not be inadvertently viewed as lack of language.

The term nonverbal has been used as equivalent to non-oral. In this line of reasoning, the systems of additional and / or alternative system of communication, like the System of Pictographic Communications (SPC) and the Bliss Communication Systems, tend to be considered as non-verbal communication systems.

According to Abercrombie 27, non-verbal corresponds to paralinguistic aspects. They express the emotional state of the subject and would also have the function of regulating the length of the conversation in progress. The adjective paralinguistic has its origins on the term paralanguage - suggested by the American linguist Archibald Hill. The latter term, however, was questioned by Abercrombie, according to which its use could lead to misunderstanding. If there is an "entity" called language, there could be another homogeneous one, called "paralanguage"

Therefore, considering that verbal refers to verb, that is, to the word, the additional and alternative systems of communication would not be non-verbal, but would be not oral. On the 1985 text, Lloyd5 presented that nonverbal was no longer used in reference to alternative and supplemental, assuming that nonverbal is a confusing denomination.

Yorston e Beukelman 28 clarify that in clinical decisions in AAC, it is important to consider the "family" of international classifications developed by the World Health Organization (OMS) to describe the state of health and health-related models that represent a real advance in the attempt to integrate the biological and social approaches for individuals with special needs.

The current Brazilian version is the International Classification of Functioning, Disability and Health (CIF-2001). According to Buchalla29, this model "(...) replaces the negative approach of disability and the inability with a positive perspective, considering the activities that the person who presents change in function and / or structure of the body can play, as well as its social participation "(op.cit., p.187).

Raghavendra et al.30 discuss the implications of its use in addition to suggesting the need for discussion of the advantages and challenges in the use of ICF in AAC. This approach should be expanded under the AAC scope in our country. This discussion will lead to the revision of concepts such as participation and performance in dealing with individuals with special needs. It should be noted that the field has been incorporated to other areas in the discussion of this classification - as papers presented on the 15th Brazilian Speech-Language Pathology and Audiology Conference (Gramado, Rio Grande do Sul, 2007) show.

\section{Conclusion}

The terminology question is very complex and dense, which means that further discussion covering professionals from different fields of knowledge should be conducted. It should also be considered that language is a dynamic and flexible process and thus, aspects, such as denominations and concepts, are subject to transformations and changes over time. This fact requires constant attention and review in order to accommodate the goals of the area and the needs and demands of the communities.

Considering the low number of publications found, in spite of the great scientific growth in this field, it is vital to encourage the dissemination of studies in indexed journals. For such, the definition of descriptors in the area is essential.

It is reiterated by the pointed aspects that the discussion of terminology consists in a reflection from which it is not possible steal, in favor of critical, responsible, scientific, and sharing use of the terms, accessible to professionals and users of the AAC and on their benefit. 
Table 1: AAC reference distributions by keyword and database

\begin{tabular}{lll} 
Keyword (brazilian) & $\begin{array}{l}\text { Number of References } \\
\text { (until 2007) }\end{array}$ & Database \\
\hline Comunicação Alternativa e Suplementar & 11 & LILACS \\
& 1 & SCIELO \\
Comunicação Alternativa & 1 & SCIELO \\
Comunicação Alternativa e Ampliada & 1 & SCIELO \\
Comunicação Alternativa e Facilitadora & 2 & LILACS \\
\hline Total & $\mathbf{1 6}$ &
\end{tabular}


Table 2 - AAC references distribution by frequency and year of publication

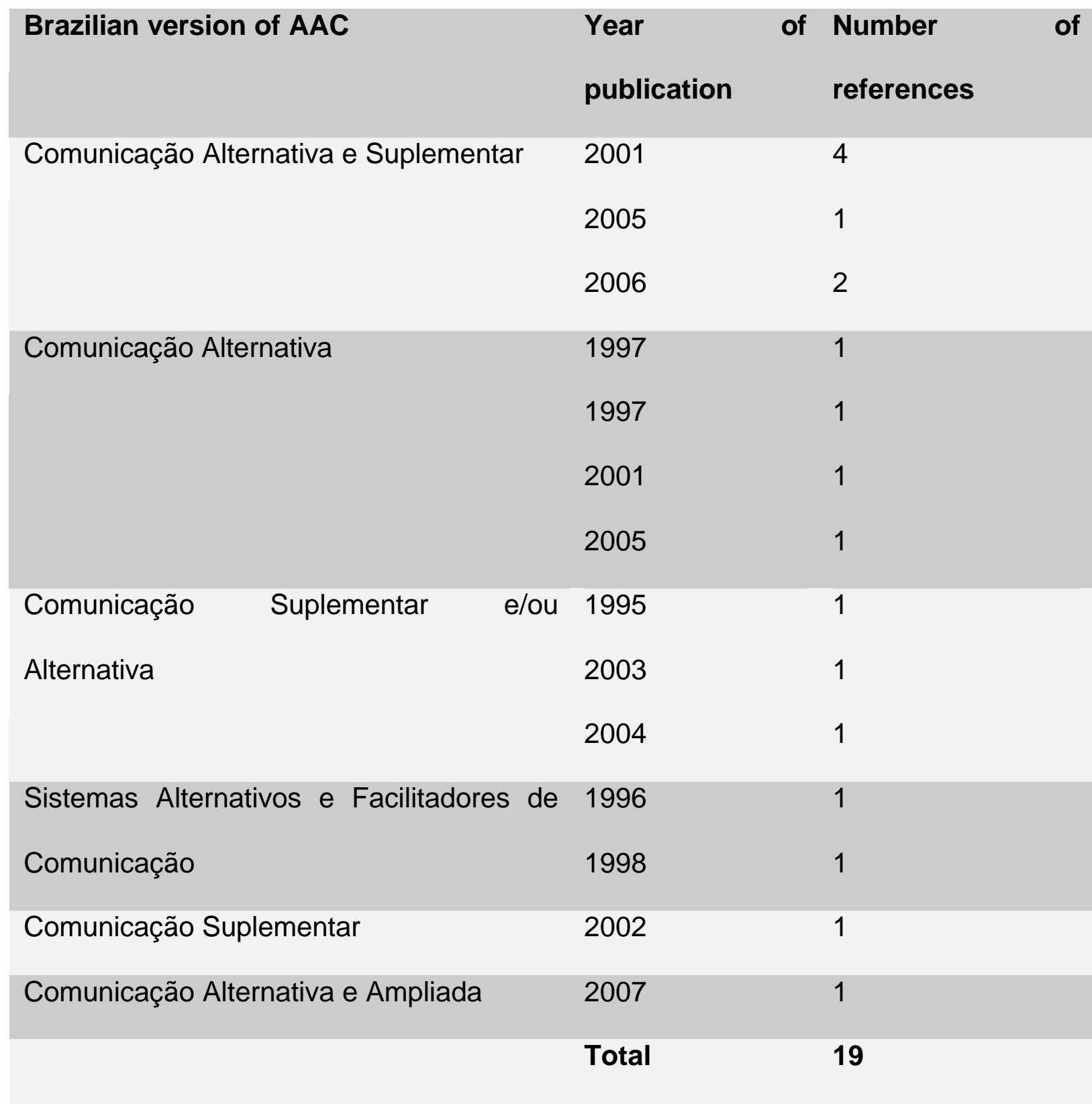




\section{Referências Bibliográficas}

1. Reily L. Sobre como o Sistema Bliss de Comunicação foi introduzido no Brasil. In: Nunes LR d'O de P, Pelosi M, Gomes MR (orgs). Um retrato da Comunicação Alternativa no Brasil: Relato de Experiências, vol II. Rio de Janeiro: 4 Pontos Estúdio Gráfico e Papéis; 2007. p. 19-45.

2. Chun RYS. O desenvolvimento da comunicação não verbal através dos símbolos Bliss em indivíduo não falante portador de paralisia cerebral. Distúr. Comun. 1991;4(2):121-36.

3. Nunes LR d'O de P. Linguagem e Comunicação Alternativa. Tese (Doutorado). Faculdade de Educação. UERJ, Rio de Janeiro; 2002.

4. Lloyd LL, Kangas K. AAC Terminology Policy and Issues Update. Augmentative and Alternative Communication. 1988;4(1):167-70.

5. Lloyd LL. Comments on Terminology. Augmentative and Alternative Communication. 1985;1(3):95-7.

6. Lloyd LL, Fuller DR. Toward an Augmentative and Alternative Communication Symbol Taxonomy: a proposed superordinated classification. Augmentative and Alternative Communication. 1986;2(4):165-71.

7. Lloyd LL, Kangas K. AAC Terminology Policy and Issues update. Augmentative and Alternative Communication. 1990;6(2):67-70.

8. Lloyd LL, Blischak DM. AAC Terminology Policy and Issues update. Augmentative and Alternative Communication. 1992;8(2):104-9.

9. Moreira EC. Comunicação Alternativa e Suplementar: as oportunidades da inclusão. Temas Desenvolv. 2001;10(58-59):69CE-74CE.

10. Panhan H. A tecnologia no espaço clínico terapêutico fonoaudiológico. Temas Desenvolv. 2001;10(5859):55CE-58CE.

11. Vasconcelos R. Paralisia cerebral e comunicação alternativa e suplementar: linguagem em funcionamento. Temas Desenvolv. 2001;10(58-59):79CE-84CE.

12. Zapata AB. A comunicaçäo como fator relevante para a viabilizaçäo da inclusão. Temas Desenvolv. 2001;10(5859):65CE-68CE.

13. Tetzchner S. Von, Brekke KM, Sjøthun B, Grindheim E. Inclusão de crianças em educação pré-escolar regular utilizando Comunicação Suplementar e Alternativa. Rev. Bras. Ed. Esp. 2005;11(2):51-184.

14. Thiers VO, Capovilla FC. Julgamento de translucência em sistemas de comunicação alternativa e suplementar por universitários. Alethéia. 2006; (24):49-56.

15. Guarda NS da, Deliberato D. Caracterização dos enunciados de um aluno não-falante usuário de recurso suplementar de comunicação durante a construção de histórias. Rev. Bras. Ed. Esp. 2006;12(2):269-88.

16. Fernandes AS. A Comunicação Alternativa na escola especial. Temas Desenvolv. 2001;10(58-59):85CE-88CE.
17. Capovilla FC, Capovilla AGS, Macedo EC. Comunicação Alternativa na USP na década de 1991-2001: tecnologia e pesquisa em reabilitação, educação e inclusão. Temas Desenvolv. 2001;10(58-59):18CE-42CE.

18. Almeida MA, Piza MHM, Lamônica, DAC. Adaptações do sistema de comunicação por troca de figuras no contexto escolar. Pró-Fono Revista de Atualização Científica. 2005, 17(2):233-40.

19. Chun RYS. Comunicação suplementar e/ou alternativa: favorecimento da linguagem de um sujeito não falante. PróFono Revista de Atualização Científica. 2003;15(1):55-64.

20. Trevizor TT, Chun RYS. O desenvolvimento da linguagem por meio do Sistema Pictográfico de Comunicação. Pró-Fono Revista Atualização Científica. 2004; 16 (3):323-32.

21. Capovilla FC, Capovilla AGS, Macedo EC de. O uso de sistemas alternativos e facilitadores de comunicaçäo nas afasias. Distúr. Comun. 1998;9(2):233-59.

22. Capovilla FC, Macedo EC de, Capovilla AGS, Duduchi M, Gonçalves M de J. O uso de sistemas alternativos e facilitadores de comunicação para o tratamento e a melhoria da qualidade de vida de afásicos. Mundo Saúde. 1996;20(10):337-42.

23. Pires SCF, Limongi SCO. Introdução de Comunicação Suplementar em pacientes com paralisia cerebral atetóide. Pró-Fono Revista Atualização Científica. 2002;14(1):5160.

24. Paula KMP de, Enumo SRF. Avaliação assistida e comunicação alternativa: procedimentos para a educação inclusiva. Rev. bras. educ. espec. 2007;13(1):3-26.

25. Gill NG. Comunicação através de símbolos: abordagem clínica baseada em diversos estudos. Temas Desenvolv. 1997;6(34):34-43.

26. Capovilla FC, Nunes L, Nunes D, Araújo I, Nogueira D. A memória de trabalho do paralisado alfabetizado: análise experimental via sistema computadorizado de comunicação alternativa. Mundo Saúde. 1997;21(2):98-101.

27. Abercrombie D. Paralanguage. In: Laver J, Hutcheson S. Communication in Face to Face Interaction. Great Britain: Penguin Books; 1968. p. 64-70.

28. Buchalla CM. A Classificação Internacional de Funcionalidade, Incapacidade e Saúde: conceitos, usos e perspectivas. Rev. Bras. Epidemiol. 2005;8(2):107-93.

29. Yorston KM, Beukelman DR. Decision Making in AAC Intervention. In: Beukelman DR, Yorston KM, Reichle J. Augmentative and Alternative Communication for adults with acquired neurologic disorders. Baltimore: Paul H. Brookes Publishing Co.; 2000. p. 55-82.

30. Raghavendra P, Bornman J, Grandlund M, BjörckAkesson E. The World Health Organization's International Classification of Functioning, Disability and Health: Implications for Clinical and Research Practice in the field of Augmentative and Alternative Communication. Augmentative and Alternative Communication. 2007;23(4):349-61. 